\title{
Search of New Tools for Weed Control Using Piptocarpha rotundifolia, a Dominant Species in the Cerrado
}

Simoni Anese, Carlos Rial, Rosa M. Varela, Ascensión Torres, José M. G. Molinillo, and Francisco A. Macías*

Cite This: J. Agric. Food Chem. 2021, 69, 8684-8694

Read Online

ACCESS $\mid$

山ll Metrics \& More

Article Recommendations

Supporting Information

ABSTRACT: Piptocarpha rotundifolia (Less.) Baker stands out as one of the species with the highest frequency, density, and relative dominance in the Cerrado formations. However, no phytochemical studies have been carried out with this species to date. The aim of this study was to evaluate the phytotoxic activity of $P$. rotundifolia leaves in the search of new environmentally friendly tools for weed control. Thus, a wheat coleoptile and phytotoxic bioassay, using relevant agricultural weeds, was used to identify the most active extracts and fractions. The subsequent purification process allowed the isolation of 11 compounds, the phytotoxicity of which was evaluated in terms of wheat coleoptile elongation and with the most sensitive weeds. Piptocarphin A was found to be the major compound and the most active. To confirm its phytotoxic potential, the effect on Ipomea grandifolia grown in a hydroponic culture and on metaxylem cells was studied. The results obtained in this study demonstrate that the inhibitory activity displayed by $P$. rotundifolia leaf extract is mainly due to the presence of piptocarphin A. The phytotoxicity shown by $P$. rotundifolia leaf extract, and the isolated compounds, on weeds could provide new tools for weed control in agricultural fields.

KEYWORDS: allelochemicals, piptocarphin A, isolation, phytotoxicity, weed control

\section{INTRODUCTION}

Among the world's important biomes, the Cerrado is considered to be one of the most diverse Savanna on the planet, with more than 12,000 plant species. ${ }^{1}$ Moreover, it has a high level of endemism, with about $44 \%$ of the Cerrado's plant species being endemic. ${ }^{2,3}$ As such, more studies are needed to identify useful Cerrado plants. The lack of knowledge about its biodiversity and possibilities is intensified by being under increasing pressure due to the expansion of agricultural frontiers in the Cerrado regions. ${ }^{4}$ Indeed, a total of 480 endemic species are expected to disappear if vegetation continues to change as a result of agricultural expansion, ${ }^{5}$ thus meaning that, once extinct, the natural resources currently present will be unavailable for subsequent exploitation. Among these, it is important to consider the discovery of natural compounds with chemical structures useful for the synthesis, for example, of natural pesticides.

Asteraceae Brecht. and J. Presl (Compositae), which is the largest family among the Angiosperms, includes 1600-1700 genera and 24,000-30,000 species, thus representing about $10 \%$ of all the world's flora. ${ }^{6}$ In Brazil, the family is represented by 290 genera and 2064 species, which are found in all the biomes, although with greater richness in the Cerrado domain, where a large number of species present high endemism. ${ }^{7}$ Asteraceae are chemically characterized by their marked ability to biosynthesize secondary metabolites with great structural diversity and a wide variety of biological activities. Among these secondary metabolites, terpenoids (mainly sesqui, di, and triterpenes and sesquiterpene lactones) and phenolic compounds (flavonoids and trans-cinnamic acid derivatives) are the most representative classes of compounds. ${ }^{8-10}$ Sesquiterpene lactones, which are the most studied group, are almost exclusive to this family and are used as chemotaxonomic markers. ${ }^{11}$ They have been identified in several species of this family such as Cynara cardunculus ${ }^{12,13}$ or sunflower. ${ }^{14}$ In addition, they exhibit a broad spectrum of biological activity, including allelopathy. ${ }^{15,16}$

Piptocarpha R. Br. (Asteraceae) is a neotropical genus that extends from southern Brazil and northern Argentina to Central America and includes approximately 50 species of shrubs and trees. ${ }^{17}$ The tree species are widely distributed throughout the southern Brazilian plateaus. One exception is Piptocarpha rotundifolia (Less.) Baker, a tree that is exclusive to the Cerrado domain of central Brazil. ${ }^{18}$ In phytosociological studies, $P$. rotundifolia stands out as one of the species with the highest frequency, density, and relative dominance in the Cerrado formations. ${ }^{19}$

Only few phytochemical studies have been carried out with plants from the genus Piptocarpha and none with P. rotundifolia. Previous studies with this genus tended to report the isolation of triterpenes, flavonoids, steroids, ${ }^{20,21}$ and sesquiterpene lactones. ${ }^{22}$ The latter, referred to as piptocarphins A-F, demonstrated cytotoxic activity in cancer cells. ${ }^{22}$ For $P$. rotundifolia, there are reports that the leaf extract presented molluscicidal activity, ${ }^{23}$ efficacy against Aedes aegypti larvae, ${ }^{24}$ and phytotoxic activity. ${ }^{25}$ The wide distribution and abundance of $P$. rotundifolia, and the lack of studies from a phytochemical

Received: March 31, 2021

Revised: July 22, 2021

Accepted: July 22, 2021

Published: July 30, 2021 

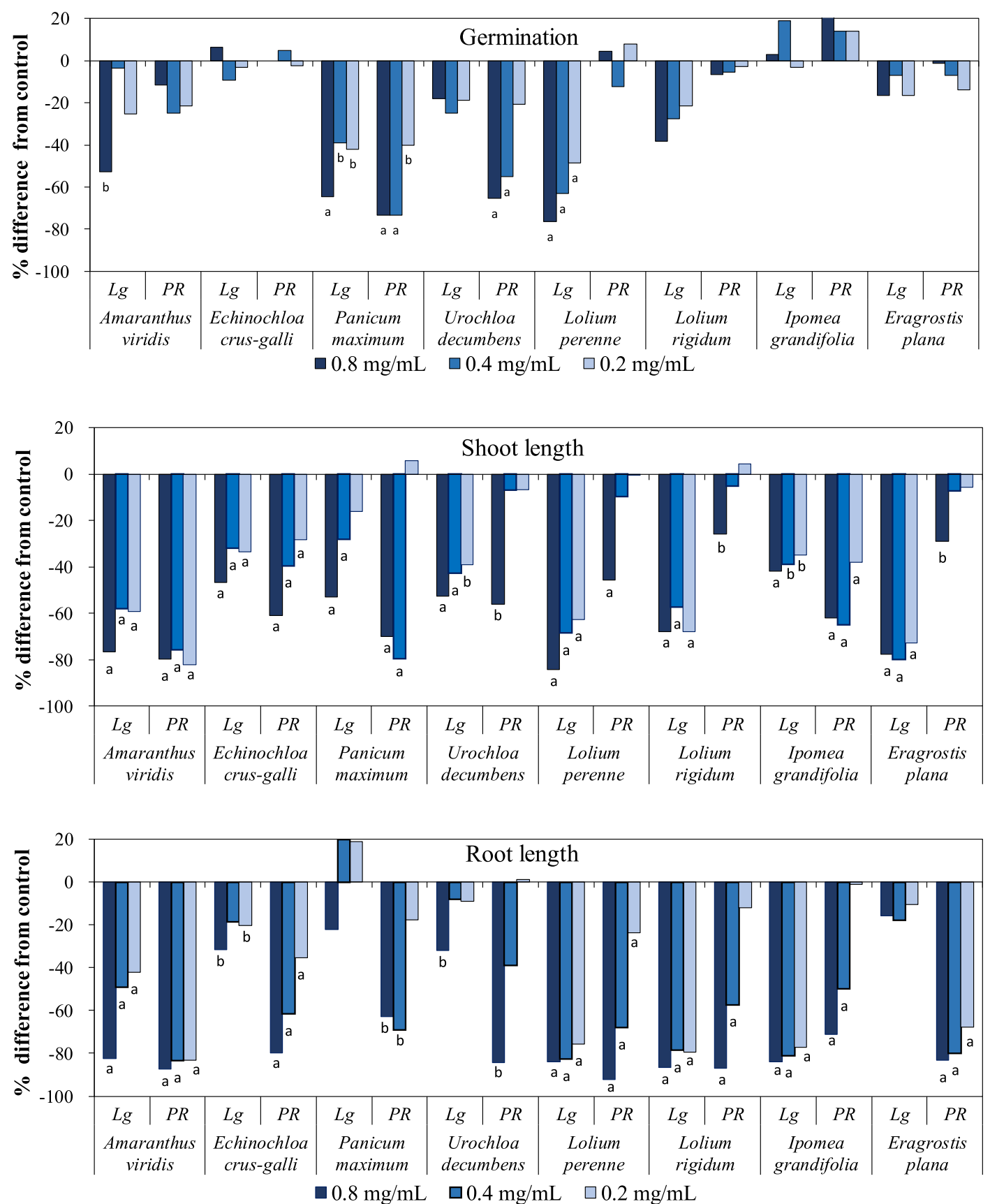

Figure 1. Effects of the herbicide Logran ( Lg) and the EtOAc fraction from Piptocarpha rotundifolia (PR) leaves on growth and germination of weed species. Values are expressed as percentage difference with respect to the control. Significance levels $p<0.01$ (a) or $0.01<p<0.05$ (b).

and biological point of view, justify the importance of studies that may provide some understanding of the potential use of this species for weed control.

Allelopathy is the science that deals with the study of positive and negative interactions among organisms that are caused by the action of chemical compounds referred to as allelochemicals. ${ }^{26}$ The study of ecological interactions between plants, such as allelopathy, may represent a useful perspective for the development of new classes of environmentally sustainable herbicides. $^{27}$ Indeed, allelochemicals such as sesquiterpene lactones have been used as models for the development of natural herbicides. Natural products are an important alternative due to their great diversity of chemical structures and possibilities of biological properties. ${ }^{16}$
The aim of this study was to evaluate the phytotoxic activity of $P$. rotundifolia leaves in the search of new environmentally friendly tools for weed control that could be used as natural herbicide models in the future. The presence of phytotoxic compounds could also explain the dominance of this species in the Cerrado biome.

\section{MATERIAL AND METHODS}

General Experimental Procedures. 400, 500, and $600 \mathrm{MHz}$ spectrometers (Agilent, Palo Alto, CA, USA) were used to acquire nuclear magnetic resonance (NMR) spectra. The chemical shift relative to the residual $1 \mathrm{H}$ signal is given in ppm of $\mathrm{CDCl}_{3}(\delta 7.25)$ and $\mathrm{MeOD}$ $(\delta 3.33) ;{ }^{13} \mathrm{C}$ signals are referenced to the solvent signals at $\delta 77.00$ and $49.0 \mathrm{ppm}$. Ultrasonic extraction was performed using an ultrasonic bath (360 W, JP Selecta, Barcelona, Spain). Silica gel 0.060-0.200, 60A from 


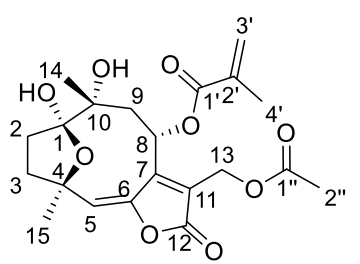

Piptocarphin A (1)



Piptocarphin C (2)

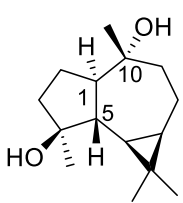

Aromadendrane-4 $\beta, 10 \alpha-$ diol (3)<smiles>COc1ccc(-c2oc3cc(O)cc(O)c3c(=O)c2OC2OC3C(O)C(O)C(O)C(O)C3OC2O)cc1O</smiles>

Tamarixetin-3-O- $\beta$-galactoside (4)<smiles>C=C(C)C(=O)O[C@H](COC(C)=O)C1=C([Hg]OC(C)=O)C(=O)O[C@@H]1/C=C(\C)CCC(=O)O</smiles>

Disyfolide (7)

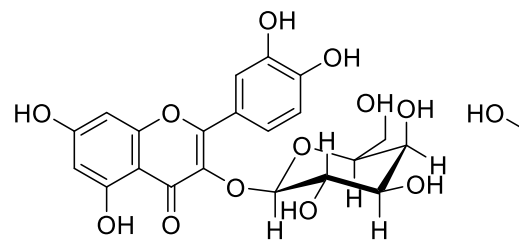

Quercetin-3-O- $\beta$-galactoside (5)<smiles>C[C@H]1CC[C@@H](O)[C@]2(C)CC[C@H](C(C)(C)O)C=C12</smiles>

$1 \alpha, 11$ - dihydroxy-5-eudesmene (8)



Quercetin-3-O- $\beta$-glucoside (6)

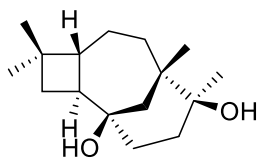

(9ß)-caryolane-1,9-diol (9)

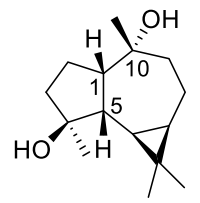

alloaromadendrane-4 $\beta, 10 \alpha$-diol (10)<smiles>C=C1CCC2C3(C)C(=C)CCC2(C(C)(C)C)C13</smiles>

Spathulenol (11)

Figure 2. Compounds isolated from P. rotundifolia leaves: piptocarphin A (1), piptocarphin C (2), aromadendrane- $4 \beta$, 10 $\alpha$-diol (3), tamarixetin-3-O$\beta$-galactoside (4), quercetin-3-O- $\beta$-galactoside (5), quercetin-3-O- $\beta$-glucoside (6), disyfolide (7), $1 \alpha$-11-dihydroxy-5-eudesmene $(8)$, (9 $\beta)$-caryolane1,9-diol (9), alloaromadendrane-4 $\beta, 10 \alpha$-diol (10), and spathulenol (11).

Acros Organics (Geel, Belgium) or LiChroprep RP $18(40-63 \mu \mathrm{m})$ from Merck (Darmstadt, Germany) was used for column chromatography. High-performance liquid chromatography (HPLC; MerckHitachi, Tokyo, Japan) with a refractive index detector was used (Elite LaChrom RI L-2490). A semipreparative column $(250 \mathrm{~mm} \times 10 \mathrm{~mm}$ i.d., $10 \mu \mathrm{m}$ LiChrospher $100 \mathrm{RP}$-18; Merck, Darmstadt, Germany) with a guard column (LiChrospher RP-18; Merck, Darmstadt, Germany) and a LiChrospher Si60 column ( $250 \mathrm{~mm} \times 10 \mathrm{~mm}$ i.d., $10 \mu \mathrm{m}$; Merck $)$ with a LiChrospher Si60 guard column (Merck) were used for HPLC.

Chloroform, $n$-hexane, methanol, dichloromethane, ethyl acetate, acetonitrile, and acetone for HPLC were purchased from VWR International (Radnor, PA, USA). MagniSolv chloroform-D1 and $\mathrm{CD}_{3} \mathrm{OD}$ (deuteration degree min. 99.8\%) for NMR spectroscopy were purchased from Merck. Water was type I and obtained from an Ultramatic system from Wasserlab (Barbatain, Spain).

Plant Material. Visibly disease-free $P$. rotundifolia leaves were collected in July 2017 from the Cerrado reserve area in the Federal Institute of Education, Science and Technology of Mato Grosso (IFMT), in the city of Campo Novo do Parecis, Mato Grosso state (Brazil, $13^{\circ} 40^{\prime} \mathrm{S}, 57^{\circ} 53^{\prime} \mathrm{W}, 572 \mathrm{~m}$ a.s.l.). The region is characterized by an Aw climate, ${ }^{28}$ with dry winters (April to September) and wet summers (October to March). One example of the species was sent to the Biology Institute at the Federal University of Uberlandia (UFU) to confirm identification, which was performed by the taxonomist Jimi Naoki Nakajima. A voucher specimen has been deposited in the herbarium at the same institution with the registration code HUFU71960. After collection, the leaves were dried at $40{ }^{\circ} \mathrm{C}$ for 72 $\mathrm{h}$ and ground into a powder with an industrial mill. This material was used in the study.

Amaranthus viridis L. and Urochloa decumbens (Stapf) R.D. Webster were purchased from Agro Cosmos (Engenheiro Coelho, Brazil).
Echinochloa crus-galli (L.) Beauv., Ipomea grandifolia (Dammer) O'Donell, Eragrostis plana Nees, Panicum maximum Jacq., Lolium perenne L., and Lolium rigidum Gaudin seeds were purchased from Herbiseed (Reading, U,K).

Phytochemical Study. Initial Extraction. An amount of $1.6 \mathrm{~kg}$ of leaf powder was subjected to aqueous extraction, in portions of $100 \mathrm{~g}$ of plant powder in $500 \mathrm{~mL}$ of distilled water, in an ultrasonic bath for 10 min (procedure repeated twice). The resulting aqueous extract was transferred to a separating funnel, in $1000 \mathrm{~mL}$ portions, and partitioned with ethyl acetate $($ EtOAc $)(3 \times 1000 \mathrm{~mL})$ to give aqueous and EtOAc fractions. The EtOAc fraction was concentrated in a rotary evaporator, at low pressure and $37^{\circ} \mathrm{C}$, and an aliquot of the initial aqueous extract (reserved previously) and the aqueous fraction were evaporated in a Savant model Speedvac SC210 vacuum centrifuge system to dryness. Finally, the activity of the initial aqueous extract and the EtOAc and aqueous fractions was evaluated in wheat coleoptile bioassays (S3). As the EtOAc fraction was found to be the most active, its activity was assayed for phytotoxicity on weeds (Figure 1).

Purification of the EtOAc Fraction. Based on the initial bioassay results, the EtOAc fraction was selected to continue the phytochemical study. For this purpose, $15 \mathrm{~g}$ of the fraction was subjected to reversephase column chromatography (filled with RP-18 silica), eluting with a $\mathrm{H}_{2} \mathrm{O} /$ methanol (MeOH) mixture (from 100:0 to 0:100 v/v, with a $20 \%$ increase; $750 \mathrm{~mL}$ of each polarity) and, finally, with dichloromethane to remove chlorophylls. After thin-layer chromatography analysis, four fractions of interest were obtained: $\mathrm{A}\left(100 \% \mathrm{H}_{2} \mathrm{O}+20 \% \mathrm{MeOH}, 1.39\right.$ g), B $\left(40 \% \mathrm{H}_{2} \mathrm{O}+60 \% \mathrm{MeOH}, 7.1 \mathrm{~g}\right), \mathrm{C}(80 \% \mathrm{MeOH}, 2.8 \mathrm{~g})$, and $\mathrm{D}$ $(100 \% \mathrm{MeOH}, 1.27 \mathrm{~g})$. Evaluation using wheat coleoptiles bioassay showed that fractions B, C, and D exhibited high inhibitory activity (S4) and, as such, these fractions were separated using chromatographic techniques for the isolation of active compounds. 
Fraction B (7.1 g) was chromatographed on a silica gel column, eluting with a chloroform $\left(\mathrm{CHCl}_{3}\right) / \mathrm{MeOH}$ gradient from 100:0 to $0: 100 \mathrm{v} / \mathrm{v}$, with a $10 \%$ increase, $500 \mathrm{~mL}$ of each polarity, to yield 14 subfractions (B1-B14). Sub-fraction B2 (1.4 g) was identified as compound 1, which was isolated pure and considered to be the major compound in the plant. Sub-fraction B4 $(1.3 \mathrm{~g})$ was purified by HPLC (semipreparative column), using the solvents hexane/EtOAc (isocratic method 35:65 v/v, flow $3 \mathrm{~mL} \mathrm{~min}{ }^{-1}$ ), to give compound 2 $(556 \mathrm{mg})$. Sub-fraction B6 $(60 \mathrm{mg})$ was purified by HPLC (RP-18 semipreparative column), eluting with $\mathrm{H}_{2} \mathrm{O} / \mathrm{MeOH}$ /acetonitrile $(\mathrm{MeCN})\left(40: 30: 30 \mathrm{v} / \mathrm{v}\right.$, flow $\left.3 \mathrm{~mL} \mathrm{~min}{ }^{-1}\right)$, to give five sub-fractions (B6.1-B6.5). Sub-fraction B6.2 (69.5 mg) was characterized as compound 2, and sub-fraction B6.4 $(28.3 \mathrm{mg})$ was purified by HPLC (RP-18 semipreparative column), using the same solvents (50:25:25 v/ $\mathrm{v}$, flow $3 \mathrm{~mL} \mathrm{~min}^{-1}$ ), to yield compound $3(11.5 \mathrm{mg})$. Sub-fractions B12 $(66 \mathrm{mg})$ and B14 (434 mg), separately, were purified by HPLC (RP-18 semipreparative column), eluting with $\mathrm{H}_{2} \mathrm{O} / \mathrm{MeOH} /$ acetone

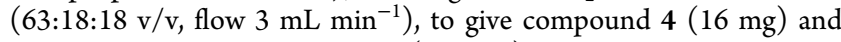
a mixture of compounds 5 and $6(217 \mathrm{mg})$, respectively.

Fraction C (2.8 g) was separated on a chromatographic column, eluting with dichloromethane/EtOAc mixtures from 0 to $100 \%$ polarity increase in $\mathrm{EtOAc}$ (5\% increase, $300 \mathrm{~mL}$ of each polarity) and ending with $100 \% \mathrm{MeOH}$, obtaining 10 sub-fractions $(\mathrm{C} 1-\mathrm{C} 10)$. Sub-fraction C3 (103 mg) was purified by HPLC (semipreparative column), using hexane/EtOAc as solvent (isocratic method 70:30 v/v, flow $3 \mathrm{~mL}$ $\left.\mathrm{min}^{-1}\right)$, to give compound $7(44.1 \mathrm{mg})$. Sub-fraction C6 $(40 \mathrm{mg})$ was purified by HPLC (RP-18 semipreparative column), eluting with $\mathrm{H}_{2} \mathrm{O}$ / $\mathrm{MeOH} /$ acetonitrile $(\mathrm{MeCN})\left(40: 30: 30 \mathrm{v} / \mathrm{v}\right.$, flow $\left.3 \mathrm{~mL} \mathrm{~min}^{-1}\right)$, to give compound 8 (C6.4-8.3 mg). Sub-fraction C7 $(60 \mathrm{mg})$ was purified by HPLC (RP-18 semipreparative column), using the same mixture of solvents and previous proportions, to give compounds 9 (C7.6-9.4 mg) and 10 (C7.8-8.3 mg). Fraction D (1 g) was chromatographed using hexane/acetone mixtures as the mobile phase, from 0 to $100 \%$ increase in acetone $(10 \%$ increase, $300 \mathrm{~mL}$ of each polarity) and ending with $100 \% \mathrm{MeOH}$, to yield eight sub-fractions (D1-D8). Subfraction D1 $(150 \mathrm{mg})$ was subjected to further fractionation using a chromatographic column using mixtures of hexane/EtOAc (100:0, 95:5, 90:10, $85: 15$, and $0: 100 \mathrm{v} / \mathrm{v} ; 100 \mathrm{~mL}$ of each polarity) as the mobile phase and ending with $100 \% \mathrm{MeOH}$, yielding four sub-fractions (D1.1-D1.4). Sub-fraction D1.2 was identified as compound 11 (19.4 mg).

The identification of the compounds (Figure 2) was achieved by using the complete physical, spectroscopic, and spectrometric data set obtained. All data correspond with those reported in the literature for the isolated compounds. All the compounds isolated were evaluated in coleoptile bioassays, and the most actives were evaluated in phytotoxicity bioassays.

Bioassays. Wheat Coleoptile Bioassay. The wheat coleoptile bioassay was performed according to the procedure previously described by Rial and co-workers ${ }^{16}$ (S1). Thus, fractions were tested at concentrations of $0.2,0.4$, and $0.8 \mathrm{mg} \mathrm{mL}^{-1}$, while isolated compounds were tested at concentrations of $10,30,100$, and $300 \mu \mathrm{M}$ and $1 \mathrm{mM}$. Each evaluated solution maintained a constant dimethyl sulfoxide (DMSO) concentration of $5 \mu \mathrm{L} / \mathrm{mL}$. Each treatment was tested in triplicate by adding $2 \mathrm{~mL}$ of each solution and five fragments of wheat coleoptile to a glass test tube $(16 \times 100 \mathrm{~mm}, 10 \mathrm{~mL})$. One control containing the buffer solution with DMSO $(5 \mu \mathrm{L} / \mathrm{mL})$ was included. The commercial herbicide Logran (terbutryn $59.4 \%$ and triasulfuron $0.6 \%$ ) was used as an internal reference, and its concentration and conditions were the same as previously reported. Welch's test was performed for statistical analysis of the data and to express it as a percentage difference relative to the control. Positive values represent stimulation, and negative values represent inhibition.

Phytotoxicity Bioassay. The ethyl acetate fraction and the most active compounds were assessed for phytotoxic activity following the procedure previously described by Rial and co-workers ${ }^{16}$ (S2) on eight agricultural weeds, which were selected because they belong to and represent important families in agricultural weeds: morning glory ( $I$. grandifolia, Convolvulaceae), barnyard grass (E. crus-galli, Poaceae), slender amaranth (A. viridis, Amaranthaceae), guinea grass ( $P$. maximum, Poaceae), brachiaria (U. decumbens, Poaceae), perennial ryegrass (L. perenne, Poaceae), annual ryegrass (L. rigidum, Poaceae), and capim-annoni (E. plana, Poaceae). In addition, the invasive grasses P. maximum, E. crus-galli, and E. plana, evaluated in the present study, are considered aggressive invasive species in Brazil, which, in addition to natural reserves such as Cerrado, harm many agricultural crops. ${ }^{29,30}$ To break the physical dormancy, I. grandifolia seeds were immersed in a concentrated sulfuric acid solution for $5 \mathrm{~min}$. After that, they were washed in water for use in the tests ${ }^{31}$

Solutions containing the fractions and the isolated compounds were tested at the same concentrations and conditions reported above. At all the concentrations tested and in the control, a constant concentration of DMSO $(5 \mu \mathrm{L} / \mathrm{mL})$ was ensured.

The experimental design was completely randomized and contained four replicates of 20 seeds for each concentration. The experiment was conducted in a germination chamber at $25^{\circ} \mathrm{C}$ with a $12 \mathrm{~h}$ photoperiod for 7 days for I. grandofolia ${ }^{31}$ and at $25{ }^{\circ} \mathrm{C}$ in the dark for the other species. Bioassays took 6 days for E. plana, A. viridis, E. crus-galli, $L$. perenne, and $L$. rigidum and 8 days for $P$. maximum and $U$. decumbens. After growth, plants were frozen at $-10{ }^{\circ} \mathrm{C}$ for $24 \mathrm{~h}$. The germination ratio, root length, and shoot length were recorded using a Fitomed system. ${ }^{32}$ The data were analyzed statistically using Welch's test, with significance fixed at 0.01 and 0.05 . The germination ratio, root length, and shoot length are presented as percentage differences with respect to the control. Zero represents control, positive values represent stimulation, and negative values represent inhibition.

Hydroponic Bioassay. For the hydroponic bioassay with the most active compound, Ipomea gradifolia seedlings were selected and grown previously in pots with a volume of $250 \mathrm{~mL}$, filled with $200 \mathrm{~g}$ of washed river sand, vermiculite, and clay in a ratio of $1: 1: 1$. Four seeds were sown in each pot, with 4 replicates per treatment. Ten days after emergence of the seedlings, water was replaced with nutrient solution as described by Hoagland and Arnon ${ }^{33}$ at $1 / 3$ ionic strength for acclimation of the seedlings, which were then transferred, 20 days post-emergence, to glass containers with a diameter of $6 \mathrm{~cm}$ and height of $15 \mathrm{~cm}$ containing solutions of the evaluated compound at different concentrations and wrapped externally with aluminum foil. As a substrate, $200 \mathrm{~g}$ of $3 \mathrm{~mm}$ diameter glass beads was used and $40 \mathrm{~mL}$ of each solution was added per container. This process ensures the germination of the seeds and allows us to select homogeneous-growth seeds and also allows us to control the concentration of the tested compound.

The pure compound was pre-dissolved in DMSO $(5 \mu \mathrm{L} / \mathrm{mL}$ solution) and diluted in nutrient solution as described by Hoagland and Arnon $^{33}$ at $1 / 3$ ionic strength and subsequently dissolved at concentrations of $1000,300,100,30$, and $10 \mu \mathrm{M}$. As a control, Hoagland and Arnon ${ }^{33}$ solution at $1 / 3$ ionic strength plus DMSO was used. Four replicates were performed for each concentration. The ends of the containers were capped with Parafilm in order to maintain moisture. The experiment was conducted for 20 days in a climatic chamber regulated at $25^{\circ} \mathrm{C}$ with a photoperiod of $12 \mathrm{~h}$. After that, the dry biomass of roots and shoots was obtained by collecting the material and packing it in paper bags followed by drying in an air circulation oven at $65-70{ }^{\circ} \mathrm{C}$ to constant mass. The results are shown as percentage differences compared to the control, as described in phytotoxic bioassay. The data were analyzed statistically using Welch's test, with significance fixed at 0.01 and 0.05 .

Analysis of Metaxylem Elements. I. grandifolia seedlings grew at different concentrations of the most active compound isolated from $P$. rotundifolia and the control for four days, under the same conditions tested in the phytotoxic study. After that, the primary root segments of the seedlings were removed and subjected to a modified Fuchs staining method. ${ }^{34}$ Briefly, the roots were immersed in $70 \%$ alcohol for five days and placed in a solution of $10 \% \mathrm{NaOH}$ at $60{ }^{\circ} \mathrm{C}$ for $48 \mathrm{~h}$ to complete clarification. The root segments were subsequently immersed in the safranin reagent $\left(\mathrm{C}_{20} \mathrm{H}_{19} \mathrm{~N}_{4} \mathrm{Cl}\right)$ and $10 \% \mathrm{NaOH}$, for $24 \mathrm{~h}$ at $60{ }^{\circ} \mathrm{C}$, as reported by Anese et al. ${ }^{31}$ After staining, the roots were mounted on glass slides with Apathy's syrup ${ }^{31,35}$ for observation under an Axio optical microscope coupled to a camera (ZEISS Axiocam ERs 5s Ver 5.0). Four primary roots of $I$. grandifolia seedlings grown at different concentrations of the compound and control were assessed. Half the length of each root from the mature region (central) toward the stem 
Table 1. $\mathrm{IC}_{50}$ Values for the EtOAc Fraction from Piptocarpha rotundifolia (PR) Leaves and the Herbicide Logran on Root and Shoot Growth of Weed Species

\begin{tabular}{|c|c|c|c|c|c|c|c|c|}
\hline & \multicolumn{4}{|c|}{ root } & \multicolumn{4}{|c|}{ shoot } \\
\hline & \multicolumn{2}{|l|}{ PR } & \multicolumn{2}{|c|}{ Logran } & \multicolumn{2}{|l|}{ PR } & \multicolumn{2}{|l|}{ Logran } \\
\hline & $\mathrm{IC}_{50}\left(\mathrm{mg} \mathrm{mL}^{-1}\right)$ & $R^{2}$ & $\mathrm{IC}_{50}\left(\mathrm{mg} \mathrm{mL}^{-1}\right)$ & $R^{2}$ & $\mathrm{IC}_{50}\left(\mathrm{mg} \mathrm{mL}^{-1}\right)$ & $R^{2}$ & $\mathrm{IC}_{50}\left(\mathrm{mg} \mathrm{mL}^{-1}\right)$ & $R^{2}$ \\
\hline Amaranthus viridis & 0.042 & 0.99 & 0.308 & 0.97 & 0.045 & 0.97 & 0.189 & 0.97 \\
\hline Echinochloa crus-galli & 0.286 & 0.99 & $a$ & & 0.562 & 0.99 & 0.843 & 0.97 \\
\hline Panicum maximum & 0.376 & 0.91 & $a$ & & 0.390 & 0.75 & 0.839 & 0.99 \\
\hline Uruchloa decumbens & 0.514 & 0.86 & $a$ & & $a$ & & 0.557 & 0.96 \\
\hline Lolium perenne & 0.284 & 0.92 & 0.061 & 0.99 & $a$ & & 0.135 & 0.99 \\
\hline Lolium rigidum & 0.376 & 0.90 & 0.056 & 0.99 & $a$ & & 0.143 & 0.91 \\
\hline Ipomea grandifolia & 0.515 & 0.90 & 0.060 & 0.99 & 0.301 & 0.97 & 0.841 & 0.95 \\
\hline Eragrostis plana & 0.093 & 0.99 & $a$ & & $a$ & & 0.072 & 0.98 \\
\hline
\end{tabular}



Figure 3. Cluster analysis of the phytotoxic activity of the EtOAc fraction from Piptocarpha rotundifolia leaves on shoot and root growth in weed species.

separation was photographed. From each image, the size of 15 metaxylem vessel elements was evaluated, at $20 \times$ magnification, ${ }^{31}$ with the aid of ZEN 2 (blue edition) software. Analysis of variance (ANOVA) followed by Scott-Knott's test at a significance level of 0.05 was performed for the data obtained.

Statistical Analysis. $\mathrm{IC}_{50}$ values for the activity inhibition data were determined by performing a non-linear regression with the GraphPad Prism 5 package (San Diego, CA, USA). Cluster analyses were performed using Statistica v.7.0 software (Tulsa, OK, USA). Squared euclidian distances and complete linkage were used for the analysis.

\section{RESULTS AND DISCUSSION}

A bioguided isolation was carried out to study the phytotoxic activity of $P$. rotundifolia. To that end, dry and crushed $P$. rotundifolia leaves were submitted for aqueous extraction and an aliquot of the resulting extract was partitioned by liquid-liquid extraction with EtOAc, resulting in the aqueous and EtOAc fractions. Aliquots of the crude aqueous extract and each fraction were evaporated to dryness and used in wheat coleoptile bioassays. The EtOAc fraction caused 100\% inhibition in the elongation of wheat coleoptiles at concentrations of 0.8 and 0.4 $\mathrm{mg} \mathrm{mL} \mathrm{m}^{-1}$. No inhibitory activity was recorded for the aqueous extract or the aqueous fraction (S3). Similar results have been observed in previous studies, which show the ethyl acetate fraction being much more active than the original aqueous extract and the aqueous fraction. ${ }^{36}$ The relevant inhibitory effect on wheat coleoptiles caused by the EtOAc fraction indicates that it has bioactive compounds with a phytotoxic effect. Subsequently, the remaining crude aqueous extract was partitioned with EtOAc to provide a larger EtOAc fraction, yielding $15 \mathrm{~g}(0.9 \%)$. The phytotoxicity levels of this fraction were evaluated using weed seeds (I. grandifolia, E. crus-galli, A. viridis, $P$. maximum, $U$. decumbens, $L$. perenne, L. rigidum, and $E$. plana) at the same concentrations as for the coleoptile wheat bioassay (Figure 1). All of these weeds are problematic in agricultural crops. ${ }^{37}$ In addition, the invasive grasses $P$. maximum, E. crus-galli, and E. plana are considered aggressive invasive species in Brazil and identified as barriers to natural regeneration and establishment of native species in the Cerrado biome, ${ }^{29,30}$ where the species $P$. rotundifolia is widely recorded.

The EtOAc fraction significantly inhibited seedling growth. Indeed, it was observed that this fraction was active in the inhibition of root and shoot growth of all species, with more pronounced effects at the highest concentration evaluated and an evident decrease in activity levels with dilution (Figure 1). In general, the inhibitory effect of the EtOAc fraction was more pronounced for primary root growth than for shoot growth of the target weed seedlings, thus corroborating other studies that evaluated the effect of extracts and fractions from allelopathic 


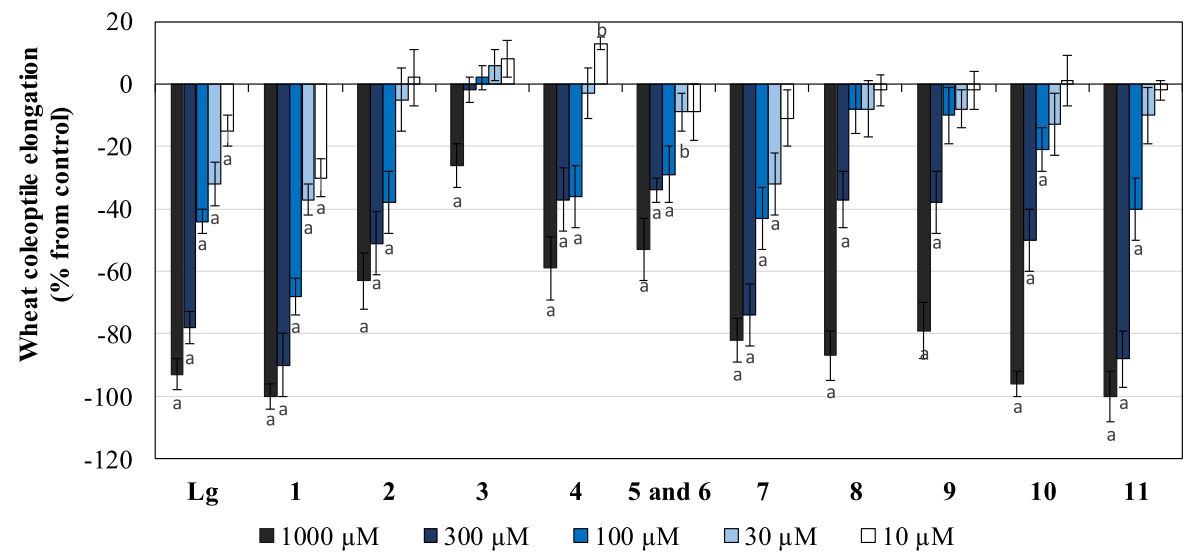

Figure 4. Effect of the herbicide Logran $(\mathrm{Lg})$ and the compounds obtained from $P$. rotundifolia leaves on wheat coleoptile elongation. Values are expressed as percentage difference with respect to the control. Each bar is the mean \pm standard deviation. Significance levels $p<0.01$ (a) or $0.01<p<$ 0.05 (b).

plants on weeds. ${ }^{35,36}$ Root growth is characterized by high metabolic rates, and for this reason, roots are highly susceptible to environmental stresses, such as allelochemicals in the substrate. ${ }^{38}$ Based on the $\mathrm{IC}_{50}$ values (Table 1 ), A. viridis was the most affected weed in terms of both root and shoot growth ( 0.042 and $0.045 \mathrm{mg} \mathrm{mL}^{-1}$, respectively). Regarding germination, the extract showed inhibitory activity on P. maximun and $U$. Decumbens, with activities higher than those of Logran.

In order to select the most sensitive species for phytotoxic bioassay, a cluster analysis was performed using the phytotoxic bioassay results of the EtOAc fraction from $P$. rotundifolia leaves (Figure 3). This analysis showed that $A$. viridis was the most sensitive species, being grouped independently. In addition, $E$. crus-galli, I. grandifolia, and P. maximum were selected as the most active at the following level. E. plana was also selected because it was grouped independently in the next level.

Isolation of Phytotoxic Compounds. The initial results showed that $P$. rotundifolia has phytotoxic activity on weed species. Identification of individual components and the evaluation of their bioactivity could facilitate the discovery of new tools for crop protection. Continuing the study, this fraction was subjected to reverse-phase column chromatography (RP18) to give four fractions of interest, which were evaluated in coleoptile bioassays. Fractions B, C, and D showed strong inhibitory activity, similar to the inhibition caused by the herbicide at the same concentrations (S4). Fractionation of these three fractions led to the isolation of 11 compounds: three sesquiterpene lactones, three flavonol glycosides, and five sesquiterpenoids (Figure 2). The identification of the compounds was achieved by using the complete physical, spectroscopic, and spectrometric data set obtained. All the data correspond with those reported in the literature for piptocarphin A (1), ${ }^{22}$ piptocarphin C (2), ${ }^{22}$ aromadendrane- $4 \beta, 10 \alpha$-diol (3), ${ }^{39}$ tamarixetin-3-O- $\beta$-galactoside (4), ${ }^{40}$ quercetin-3-O- $\beta$ galactoside $(5),{ }^{41}$ and quercetin-3-O- $\beta$-glucoside $(6),{ }^{42}$ isolated from fraction $\mathrm{B}$, disyfolide $(7),{ }^{43} 1 \alpha$-11-dihidroxy-5-eudesmene $(8),{ }^{44}(9 \beta)$-caryolane-1,9-diol (9), ${ }^{45}$ and alloaromadendrane$4 \beta, 10 \alpha$-diol (10), ${ }^{46}$ isolated from fraction $\mathrm{C}$, and spathulenol (11) ${ }^{39}$ isolated from fraction D. All compounds were isolated and reported for the first time in $P$. rotundifolia, and the phytotoxicity of some of them has been already reported. ${ }^{4-49}$ Their phytotoxic activities were evaluated in coleoptile bioassay (Figure 4).
Wheat Coleoptile Bioassay with Isolated Compounds. The sesquiterpene lactone piptocarphin A (1) caused the highest percentage inhibition in the wheat coleoptile elongation assay, resulting in inhibition of 100 and $90 \%$, respectively, at the concentrations of 1000 and $300 \mu \mathrm{M}$ (Figure 4). The sesquiterpene spathulenol (11) also showed strong inhibition, reaching $98 \%$ at the highest concentration evaluated. These values for both compounds were even higher than those achieved using the herbicide Logran. The coleoptile bioassay results allowed us to calculate the $\mathrm{IC}_{50}$ value for each product evaluated and to organize the compounds according to their phytotoxicity (Table 2 ). The activity shown by the compounds

Table 2. $\mathrm{IC}_{50}$ Values for the Herbicide Logran and the Compounds Obtained from $P$. rotundifolia Leaves on Wheat Coleoptile Elongation

\begin{tabular}{lcc} 
& \multicolumn{2}{c}{ wheat coleoptile } \\
\cline { 2 - 3 } $\mathbf{1}$ & $\mathrm{IC}_{50}(\mu \mathrm{M})$ & $R^{2}$ \\
Logran & 48.4 & 0.99 \\
$\mathbf{7}$ & 105.0 & 0.99 \\
$\mathbf{1 1}$ & 105.9 & 0.98 \\
$\mathbf{2}$ & 116.9 & 0.97 \\
$\mathbf{1 0}$ & 239.6 & 0.96 \\
$\mathbf{4}$ & 267.7 & 0.97 \\
$\mathbf{8}$ & 380.6 & 0.93 \\
$\mathbf{9}$ & 414.4 & 0.97 \\
$\mathbf{5}$ and $\mathbf{6}$ & 439.3 & 0.98 \\
$\mathbf{3}$ & 784.3 & 0.97
\end{tabular}

${ }^{a_{5}}{ }_{5} \%$ inhibition was not achieved at the highest concentration.

correlated with that obtained for fractions in the coleoptile bioassays (S4). Thus, some of the most active compounds, with activity levels similar to, or even higher than, the Logran herbicide were isolated from the most active fractions. For example, piptocarphin A (1) and piptocarphin B (2) were isolated from fraction $B$, spathulenol (11) from fraction $D$, and disyfolide (7) from fraction C. The sesquiterpenes $1 \alpha-11$ dihydroxy-5-eudesmene (8), (9ק)-caryolane-1,9-diol (9), and alloaromadendrane- $4 \beta, 10 \alpha$-diol (10), which showed high inhibition values at $1000 \mu \mathrm{M}$, were also isolated from fraction $\mathrm{C}$, although this activity decreased significantly for the other concentrations evaluated (Figure 4). This fast decrease in 

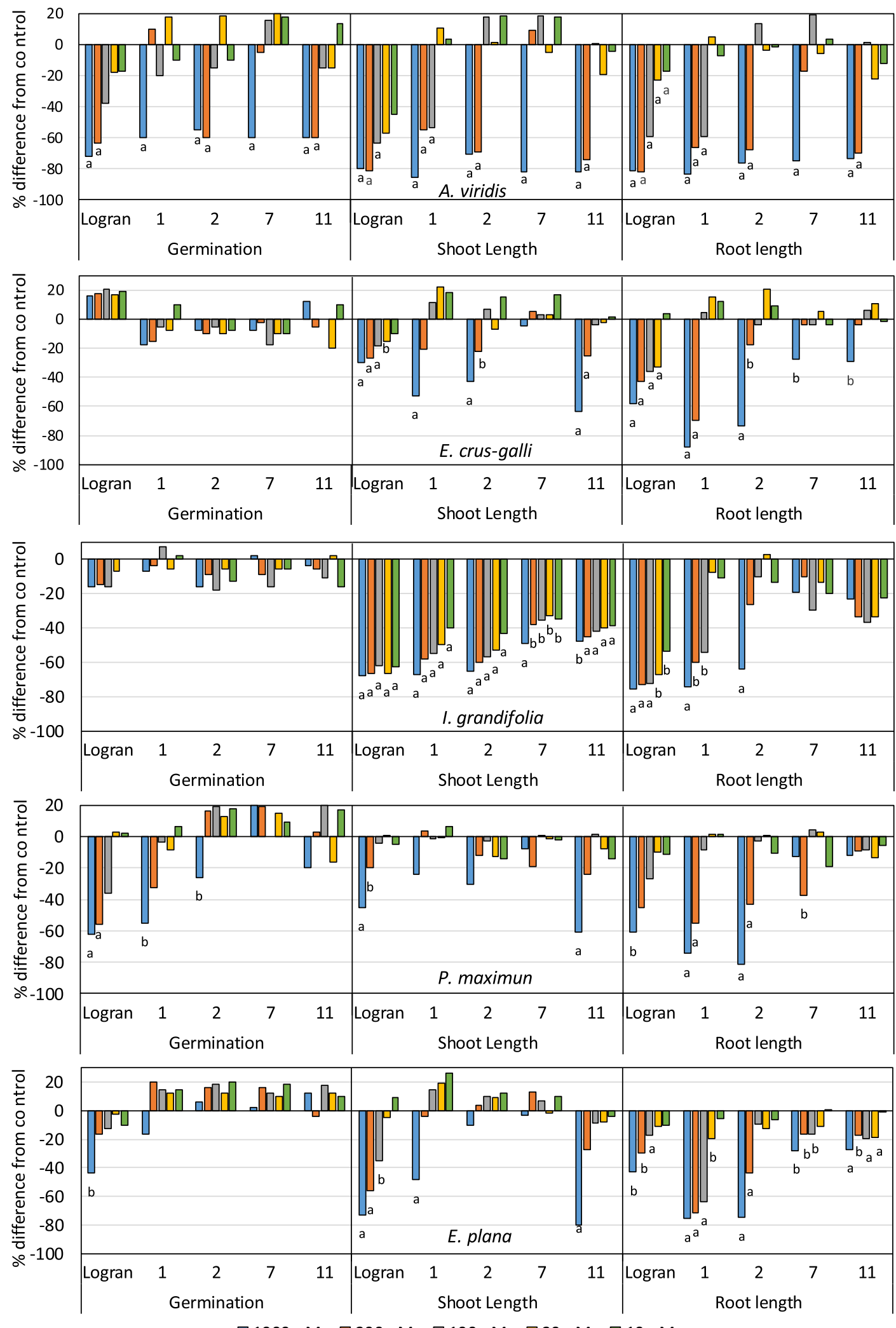

$\square 1000 \mu \mathrm{M} \quad \square 300 \mu \mathrm{M} \quad \square 100 \mu \mathrm{M} \quad \square 30 \mu \mathrm{M} \quad \square 10 \mu \mathrm{M}$

Figure 5. Effect of the herbicide Logran $(\mathrm{Lg})$ and the compounds obtained from P. rotundifolia leaves on the germination and growth of weeds. Values are expressed as percentage difference with respect to the control. Significance levels $p<0.01$ (a) or $0.01<p<0.05$ (b).

activity with the dilution has been previously reported for other sesquiterpenes. $^{16,50}$

In view of the results, a SAR study could be carried out. First, sesquiterpenes have shown higher activity than flavones. In addition, sesquiterpene lactones seem to be a bit more active. In the case of piptocarphins and disyfolide, acetylation of the hydroxyl group at C13 increases substantially their phytotoxicity. However, hydroxyl groups at positions $\mathrm{C} 1$ and $\mathrm{C} 10$ 
Table 3. $\mathrm{IC}_{50}$ Values for the Herbicide Logran and the Compounds Obtained from P. rotundifolia Leaves on the Growth of Weeds

\begin{tabular}{|c|c|c|c|c|c|c|c|c|c|c|}
\hline & \multicolumn{2}{|c|}{ Eragrostis plana } & \multicolumn{2}{|c|}{ Echinochloa crus-galli } & \multicolumn{2}{|c|}{ Panicum maximum } & \multicolumn{2}{|c|}{ Amaranthus viridis } & \multicolumn{2}{|c|}{ Ipomea grandifolia } \\
\hline & $\begin{array}{l}\text { shoot } \mathrm{IC}_{50} \\
\mu \mathrm{M}\left(R^{2}\right)\end{array}$ & $\begin{array}{l}\operatorname{root} \mathrm{IC}_{50} \\
\mu \mathrm{M}\left(R^{2}\right)\end{array}$ & $\begin{array}{c}\text { shoot } \mathrm{IC}_{50} \\
\mu \mathrm{M}\left(R^{2}\right)\end{array}$ & $\begin{array}{l}\operatorname{root} \mathrm{IC}_{50} \\
\mu \mathrm{M}\left(R^{2}\right)\end{array}$ & $\begin{array}{l}\text { shoot } \mathrm{IC}_{50} \\
\mu \mathrm{M}\left(R^{2}\right)\end{array}$ & $\begin{array}{l}\text { root } \mathrm{IC}_{50} \\
\mu \mathrm{M}\left(R^{2}\right)\end{array}$ & $\begin{array}{c}\text { shoot } \mathrm{IC}_{50} \\
\mu \mathrm{M}\left(R^{2}\right)\end{array}$ & $\begin{array}{l}\operatorname{root} \mathrm{IC}_{50} \\
\mu \mathrm{M}\left(R^{2}\right)\end{array}$ & $\begin{array}{c}\text { shoot } \mathrm{IC}_{50} \\
\mu \mathrm{M}\left(R^{2}\right)\end{array}$ & $\begin{array}{l}\text { root } \mathrm{IC}_{50} \\
\mu \mathrm{M}\left(R^{2}\right)\end{array}$ \\
\hline Logran & $196.8(0.98)$ & $a$ & $a$ & $438.2(0.88)$ & $a$ & $475.0(0.98)$ & $13.9(0.93)$ & $71.3(0.98)$ & $6.1(0.92)$ & $6.2(0.93)$ \\
\hline 1 & $a$ & $69.2(0.96)$ & $776.0(0.96)$ & $257.8(0.91)$ & $a$ & $328.9(0.97)$ & $151.5(0.93)$ & $116.0(0.93)$ & $15.0(0.81)$ & $129.6(0.92)$ \\
\hline 2 & $a$ & $444.4(0.98)$ & $a$ & $580.5(0.95)$ & $a$ & $434.0(0.96)$ & $327.6(0.87)$ & $330.2(0.87)$ & $10.9(0.81)$ & $723.2(0.97)$ \\
\hline 7 & $a$ & $a$ & $a$ & $a$ & $a$ & $a$ & $799.2(0.83)$ & $701.4(0.90)$ & $a$ & $a$ \\
\hline 11 & $541.3(0.97)$ & $a$ & $697.8(0.99)$ & $a$ & $927.6(0.96)$ & $a$ & $261.0(0.85)$ & $318.9(0.89)$ & $a$ & $a$ \\
\hline
\end{tabular}

${ }^{a} 50 \%$ inhibition was not achieved at the highest concentration.

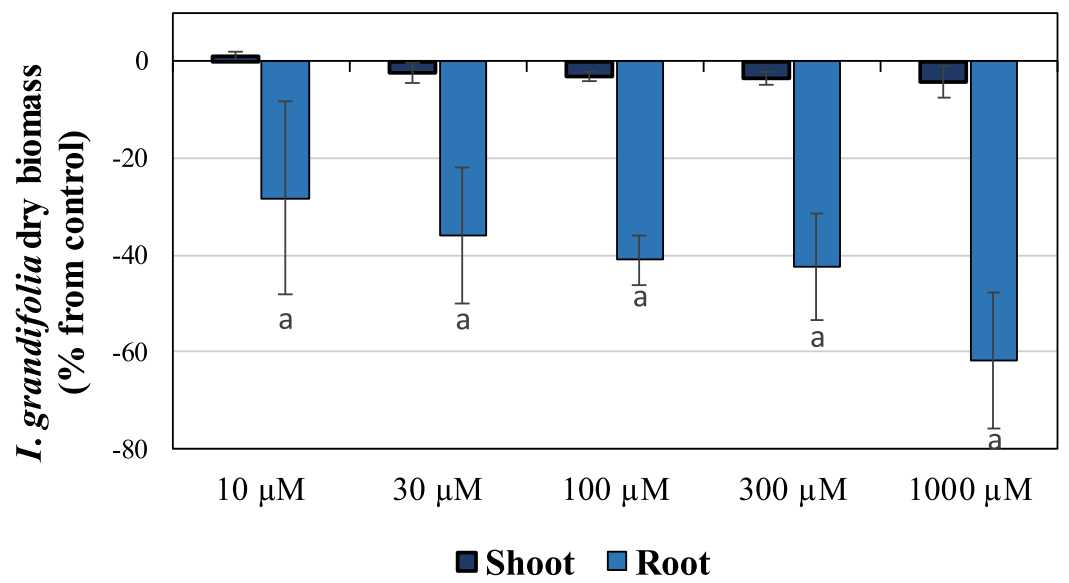

Figure 6. Effect of piptocarphin A obtained from P. rotundifolia leaves on the dry shoot and root biomass of I. grandifolia grown under hydroponic conditions. Values are expressed as percentage difference with respect to the control. Vertical bars represent standard deviations. Significance levels $p<$ 0.01 (a) or $0.01<p<0.05$ (b).

increase the activity. Regarding compounds 3, 10, and 11, a SAR study is ambiguous. On one hand, comparing 3 and 11, the presence of the double bond at C10 instead of a hydroxyl group seems crucial for the bioactivity. However, on the other hand, comparing 3 and 10, we can conclude that the configuration of $\mathrm{C} 1$ and $\mathrm{C} 5$ is also involved in their phytotoxicity.

Phytotoxic Bioassay of the Most Active Compounds. The compounds selected were 1, 2, 7, 10, and 11 for their higher activity in wheat coleoptile bioassays and according to the IC50 values (Table 2). However, 10 could not be evaluated due to the low quantity isolated. They were evaluated in phytotoxicity bioassays of the most sensitive weed seeds selected using the cluster analysis in Figure 3, namely, A. viridis, E. crus-galli, I. grandifolia, P. maximum, and E. plana.

Seed germination was the parameter least affected by the compounds studied. Piptocarphin A (1) was active on $P$. maximum germination, with an inhibition similar to that for the herbicide (60\% inhibition) at a concentration of $1000 \mu \mathrm{M}$. The germination of $A$. viridis was found to be sensitive to the effect of compounds 1, 2, 7, and 11 (Figure 5). For shoot length, $A$. viridis was sensitive to the inhibitory effects of compounds $1\left(\mathrm{IC}_{50}=\right.$ $151.5 \mu \mathrm{M}), 2\left(\mathrm{IC}_{50}=327.6 \mu \mathrm{M}\right)$, and $11\left(\mathrm{IC}_{50}=261.0 \mu \mathrm{M}\right)$ (Table 3), only at the highest concentrations, and I. grandifolia was sensitive to the inhibitory effects of compounds $1\left(\mathrm{IC}_{50}=\right.$ $15.0 \mu \mathrm{M})$ and $2\left(\mathrm{IC}_{50}=10.9 \mu \mathrm{M}\right)$. The shoot length of the others weeds was scarcely influenced by these compounds, with inhibition values between 20 and $60 \%$ for compounds 1, 2, and 11, depending on the species evaluated (Figure 5).

Root growth was the most affected parameter in all weeds tested, with the sesquiterpene lactones piptocarphin A (1) and piptocarphin C (2) showing a stronger inhibitory activity than the other compounds. Piptocarpin A (1) was even more active than the herbicide Logran in some weed species (Figure 5 and Table 3).

Fast loss of activity, as previously reported in coleoptile bioassay, was also observed for all parameters and weeds tested with the dilution, except for I. grandifolia shoot length, being very active at high concentrations but losing the activity completely at low doses.

To confirm the most active compound, a cluster analysis was carried out using the germination and the root and shoot length of all weeds tested (S5). With regard to the cluster analysis, piptocarphin A (1), which was grouped independently, was the most active compound, with piptocarphin C (2) and spathulenol (11) being grouped together at the second level. Disyfolide (7), which was classified far away from piptocarphin $\mathrm{A}$ in the cluster, was identified as the least active compound.

To summarize the phytotoxic bioassay, the sesquiterpene lactone piptocarphin A (1) was the compound isolated in the largest quantity from $P$. rotundifolia leaves and also the one that contributed most to the phytotoxic activity exhibited by the plant in this study for all parameters evaluated. The second compound isolated in the highest quantities from the plant, piptocarphin C (2), also demonstrated good levels of inhibitory effects, particularly on weed root growth. The inhibitory activity of the sesquiterpene spathulenol (11) on some species in this study should also be highlighted.

Hydroponic Bioassay of piptocarphin A (1). To assess the phytotoxic potential of the most active compounds, piptocarphin A was measured under hydroponic conditions in the next level of bioassays. I. grandifolia was chosen for this hydroponic bioassay because compound $\mathbf{1}$ inhibited its growth 


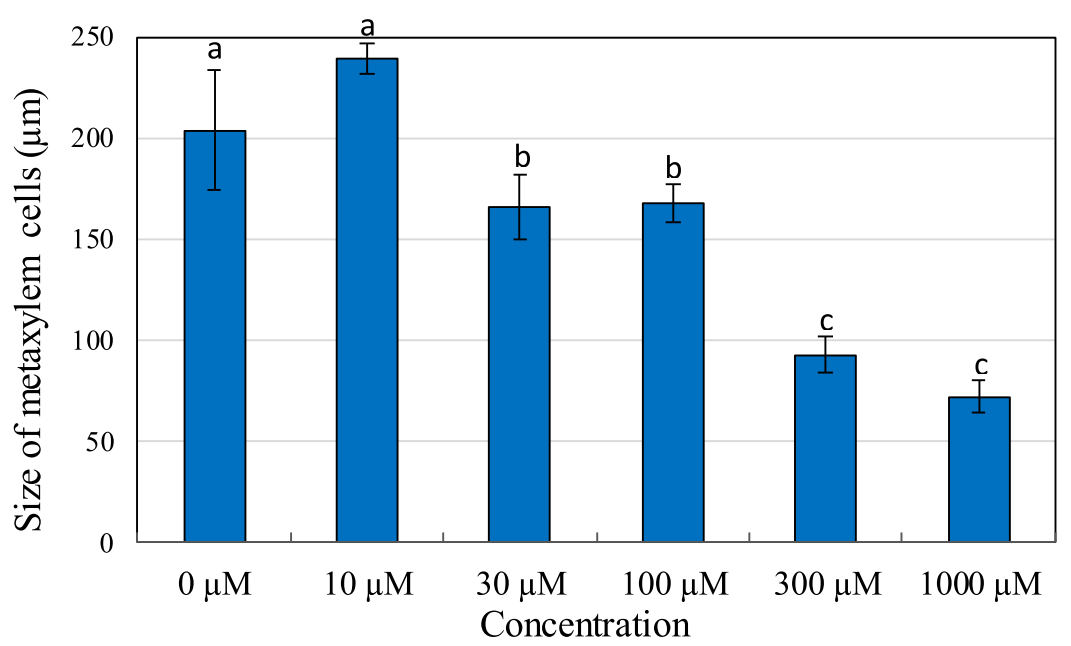

Figure 7. Size of metaxylem cells $(\mu \mathrm{m})$ in I. grandifolia seedlings roots treated with compound 1 (piptocarphin A) at various concentrations. Treatments with different letters differ by Scott-Knott's test at a probability of 0.05 . Vertical bars represent standard deviations.

at high percentage and low doses, for shoots and roots (Figure 5 and Table 3). Although the biomass accumulation in shoots was not affected by piptocarphin A, the dry weight of I. grandifolia roots was significantly reduced, and the dry biomass yield was reduced by 40 and $60 \%$ at concentrations of 300 and $1000 \mu \mathrm{M}$, respectively (Figure 6). Phytotoxic substances could directly affect the development and accumulation of dry biomass as they interfere with cell division, membrane permeability, and enzyme activity, as reported by da Silva et al. ${ }^{51}$ and Teerarak et al. ${ }^{52}$

Study of Root Metaxylem Elements. The evaluation of root anatomic aspects of the I. grandifolia allowed a detailed understanding of the action of piptocarphin A on the primary components of vascular tissue. In the primary growth, the metaxylem elements start their differentiation late and only complete their maturation after the elongation process has been completed. Therefore, they are less affected than the tissues around them. ${ }^{53}$ Beyond this, the presence of thick cell walls in the elements of the metaxylem makes it more rigid than the protophloem and also allows this tissue to be better observed as an anatomical character for analysis. Piptocarphin A strongly reduced the length of root metaxylem elements of I. grandifolia. Although in the control, the metaxylem elements reached an average size of $204 \mu \mathrm{m}$, in the seedlings grown under the action of piptocarphin A, the recorded sizes were 168,93 , and $72 \mu \mathrm{m}$, respectively, for concentrations of 100,300 , and $1000 \mu \mathrm{M}$ (Figures 7 and 8).

From the data distributed as relative frequencies (\%) of size class, it was found that in the control treatment, there was a homogeneous distribution of metaxylem element size, with the highest value of frequency $(22.5 \%)$ found for elements belonging to the size between 200 and $240 \mu \mathrm{m}$ (S6). Different from the control, in treatments with piptocarphin $\mathrm{A}$, the predominant metaxylem elements sizes were 80-120 $\mu \mathrm{m}(40 \%)$ and $40-80 \mu \mathrm{m}(70 \%)$, respectively, for concentrations of 300 and $1000 \mu \mathrm{M}$. No elements larger than $160 \mu \mathrm{m}$ were recorded at the $1000 \mu \mathrm{M}$ (S6). These results corroborate that piptocarphin A can inhibit root growth of I. grandifolia by interfering in the development of metaxylem vessel elements.

The results demonstrate that the inhibitory activity of $P$. rotundifolia leaf extract is due to the presence of piptocarphin A, the sesquiterpene lactone isolated in greater quantity and also the most active in this study. This study represents the first report on the phytotoxic activity of this compound in weed seed

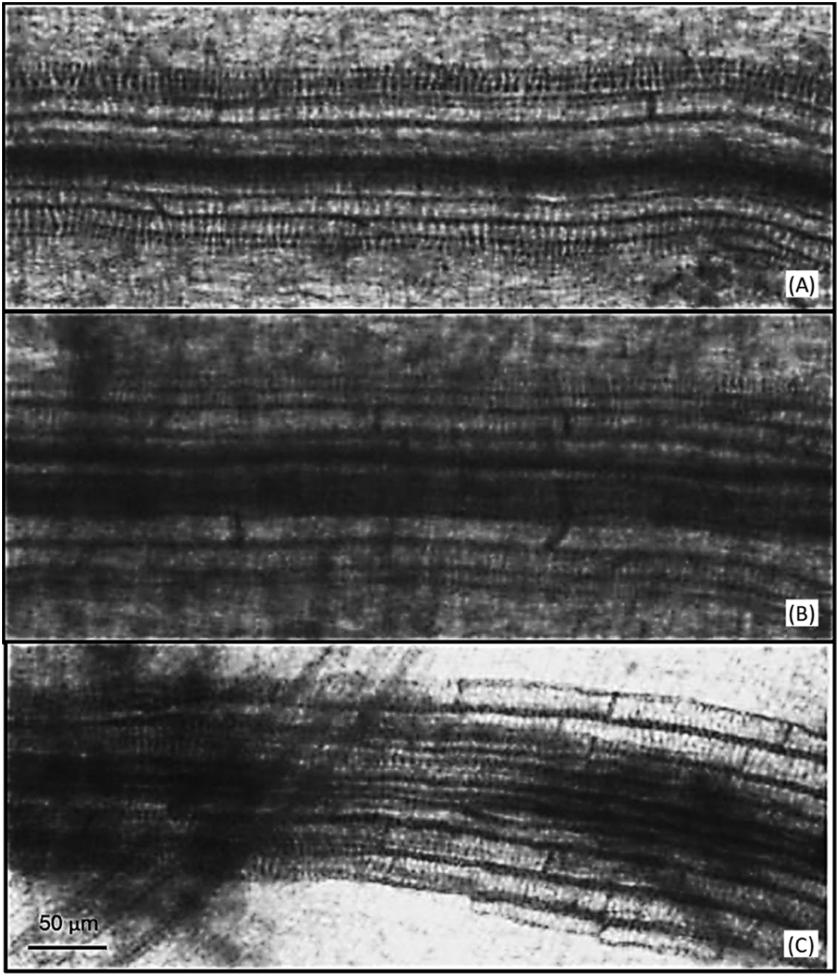

Figure 8. Photomicrographs of root metaxylem cells of I. grandifolia seedlings grown in the presence of (A) control and at concentrations of (B) 100 and (C) $1000 \mu \mathrm{M}$ of compound $\mathbf{1}$ (piptocarphin A). Scale $=50$ $\mu \mathrm{m}$.

bioassays, hydroponic culture, and an anatomical study of metaxylem cells in which weeds with relevant agricultural importance were affected. This work represents one approach for the use of $P$. rotundifolia for weed control in agriculture by using its metabolites as natural herbicide leads. It also opens future perspective to investigate the presence of synergistic effects between the compounds to increase the bioactivity, as observed in the fractions. Also, the possible use of extract or enriched fractions for the formulation of natural herbicides is an interesting research that must be developed in the future. 


\section{ASSOCIATED CONTENT}

\section{SI Supporting Information}

The Supporting Information is available free of charge at https://pubs.acs.org/doi/10.1021/acs.jafc.1c01880.

Wheat coleoptile and phytotoxic bioassay protocols; effects of crude $P$. rotundifolia aqueous leaf extracts, the EtOAc and aqueous fractions and the sub-fractions obtained from the EtOAc fraction on wheat coleoptile elongation; cluster analysis of the phytotoxic activity of the compounds obtained from $P$. rotundifolia leaves on the germination and growth of weeds; and relative frequencies (\%) of size classes of metaxylem cells from the roots of I. grandifolia seedlings grown with the control solution and in the presence of various concentrations of piptocarpin A (PDF)

\section{AUTHOR INFORMATION}

\section{Corresponding Author}

Francisco A. Macías - Allelopathy Group, Department of Organic Chemistry, Institute of Biomolecules (INBIO), Campus de Excelencia Internacional (ceiA3), School of Science, University of Cadiz, Cadiz 11510, Spain; ○ orcid.org/0000-0001-8862-2864; Email: famacias@ uca.es

\section{Authors}

Simoni Anese - Federal Institute of Education, Science and Technology of Mato Grosso, Campo Novo do Parecis, MT 78360-000, Brazil

Carlos Rial - Allelopathy Group, Department of Organic Chemistry, Institute of Biomolecules (INBIO), Campus de Excelencia Internacional (ceiA3), School of Science, University of Cadiz, Cadiz 11510, Spain; 이이.org/0000-00020265-9584

Rosa M. Varela - Allelopathy Group, Department of Organic Chemistry, Institute of Biomolecules (INBIO), Campus de Excelencia Internacional (ceiA3), School of Science, University of Cadiz, Cadiz 11510, Spain; 이이. orcid.org/0000-00033616-9134

Ascensión Torres - Allelopathy Group, Department of Organic Chemistry, Institute of Biomolecules (INBIO), Campus de Excelencia Internacional (ceiA3), School of Science, University of Cadiz, Cadiz 11510, Spain

José M. G. Molinillo - Allelopathy Group, Department of Organic Chemistry, Institute of Biomolecules (INBIO), Campus de Excelencia Internacional (ceiA3), School of Science, University of Cadiz, Cadiz 11510, Spain; (1) orcid.org/0000-0002-7844-9401

Complete contact information is available at: https://pubs.acs.org/10.1021/acs.jafc.1c01880

\section{Funding}

This research was supported by CAPES - Coordination for the Improvement of Higher Education Personnel (Brazil), (Project 88881.119937/2016-01) and "Ministerio de Economia, Industria y Competitividad” (MINEICO), Spain, Project AGL201788-083-R

\section{Notes}

The authors declare no competing financial interest.

\section{ACKNOWLEDGMENTS}

The authors thank FITÓ S.A. (Barcelona, Spain) for supplying wheat seeds.

\section{REFERENCES}

(1) Klink, C. A.; Machado, R. B. Conservation of the Brazilian Cerrado. Conserv. Biol. 2005, 19, 707-713.

(2) Cardoso Da Silva, J. M.; Bates, J. M. Biogeographic patterns and conservation in the South American Cerrado: a tropical savanna hotspot. Bioscience 2002, 52, 225-233.

(3) Myers, N.; Mittermier, A. R.; Mittermier, C. G.; Fonseca, G. A. B.; Kent, J. Biodiversity hotspots for conservation priorities. Nature 2000, 403, 853-858.

(4) Ferreira, M. E.; Ferreira, L. G.; Latrubesse, E. M.; Miziara, F. Considerations about the land use and conversion trends in the savanna environments of Central Brazil under a geomorphological perspective. J. Land Use Sci. 2016, 11, 33-47.

(5) Strassburg, B. B. N.; Brooks, T.; Feltran-Barbieri, R.; Iribarrem, A.; Crouzeilles, R.; Loyola, R.; Latawiec, A. E.; Oliveira Filho, F. J. B.; De Scaramuzza, C. A. M.; Scarano, F. R.; et al. Moment of truth for the Cerrado hotspot. Nat. Ecol. Evol. 2017, 1, 1-3.

(6) Funk, V. A.; Bayer, R. J.; Keeley, S.; Chan, R.; Watson, L.; Gemeinholzer, B.; Schilling, E. E.; Panero, J. L.; Baldwin, B. G.; GarciaJacas, N.; et al. Everywhere but Antarctica: Using a supertree to understand the diversity and distribution of the Compositae. Biol. Skr. 2005, 55, 343-373.

(7) Zappi, D. C.; Filardi, R.; Fabiana, L.; Leitman, P.; Souza, V. C.; Walter, B. M. T.; Pirani, J. R.; Morim, M. P.; Queiroz, L. P.; Cavalcanti, T. B.; Mansano, V. F.; et al. Growing knowledge: an overview of seed plant diversity in Brazil. Rodriguesia 2015, 66, 1085-1113.

(8) Sülsen, V. P.; Lizarraga, E.; Mamadalieva, N. Z.; Lago, J. H. G. Potential of terpenoids and flavonoids from Asteraceae as antiinflammatory, antitumor, and antiparasitic agents. J. Evidence-Based Complementary Altern. Med. 2017, 2017, 6196198.

(9) Keles, L. C.; Melo, N. I.; De Aguiar, G. D. P.; Akemi, K.; Wakabayashi, L.; Carvalho, E.; De Roberto, W.; Eduardo, A.; Crotti, M.; Pesquisas, N.; et al. Lychonophorinae (Asteraceae): a survey of ITS chemical constituintes and biological activities. Quim. Nova 2010, 33, 2245-2260.

(10) Lusa, M. G.; Martucci, M. E. P.; Loeuille, B. F. P.; Gobbo-Neto, L.; Appezzato-da-Glória, B.; Da Costa, F. B. Characterization and evolution of secondary metabolites in Brazilian Vernonieae (Asteraceae) assessed by LC-MS fingerprinting. Bot. J. Linn. Soc. 2016, 182, 594-611.

(11) Da Costa, F. B.; Terfloth, L.; Gasteiger, J. Sesquiterpene lactonebased classification of three Asteraceae tribes: A study based on selforganizing neural networks applied to chemosystematics. Phytochemistry 2005, 66, 345-353.

(12) Scavo, A.; Rial, C.; Molinillo, J. M. G.; Varela, R. M.; Mauromicale, G.; Macías, F. A. Effect of shading on the sesquiterpene lactone content and phytotoxicity of cultivated cardoon leaf extracts. J. Agric. Food Chem. 2020, 68, 11946-11953.

(13) Scavo, A.; Rial, C.; Varela, R. M.; Molinillo, J. M. G.; Mauromicale, G.; Macias, F. A. Influence of genotype and harvest time on the Cynara cardunculus L. sesquiterpene lactone profile. J. Agric. Food Chem. 2019, 67, 6487-6496.

(14) Rial, C.; Varela, R. M.; Molinillo, J. M. G.; Peralta, S.; Macías, F. A. Sunflower metabolites involved in resistance mechanisms against broomrape. Agronomy 2021, 11, 501.

(15) Macías, F. a.; Fernández, A.; Varela, R. M.; Molinillo, J. M. G.; Torres, A.; Alves, P. L. C. a. Sesquiterpene lactones as allelochemicals. J. Nat. Prod. 2006, 69, 795-800.

(16) Rial, C.; Varela, R. M.; Molinillo, J. M. G.; Bautista, E.; Hernández, A. O.; Macías, F. A. Phytotoxicity evaluation of sesquiterpene lactones and diterpenes from species of the Decachaeta, Salvia and Podachaenium genera. Phytochem. Lett. 2016, 18, 68-76. 
(17) Grokoviski, L.; Cervi, A. C.; Tardivo, R. C. O gênero Piptocarpha R. Br. (Asteraceae: Vernonieae) no Estado do Paraná. Brasil. Acta Bot. Bras. 2009, 23, 486-498.

(18) Volet, D. P. Estudo floristico em taxonômico do gênero Piptocarpha R. Br. (Asteraceae: Vernonieae) no estado de São Paulo, Brasil, Universidade Estadual de Campinas, 2017.

(19) Lopes, R. D. M. F.; Freitas, V. L. D. O.; Barbosa, P. M. M. Estrutura do componente arbóreo em áreas de cerrado no municipio de São Tomé das Letras, MG. Rev. Árvore 2013, 37, 801-813.

(20) Bohlmann, F.; Zdero, C.; King, R. M.; Robinson, H. Seven guaianolides from the tribe vernonieae. Phytochemistry 1980, 19, 26692673.

(21) Herz, W.; Kulanthaivel, P. Piptocarphol esters from. Piptocarpha opaca. Phytochemistry 1983, 22, 1286-1287.

(22) Cowall, P. L.; Cassady, J. M.; Chang, C.; Kozlowski, J. F. Isolation and struture determination of piptocarphin A-F, cytotoxic germacranolide lactones from. Piptocarpha chontalensis. J. Org. Chem. 1981, 46, $1114-1120$

(23) Mendes, N. M.; Queiroz, R. O.; Grandi, T. S.; Anjos, A. M.; Oliveira, A. B.; Zani, C. L. Screening of Asteraceae (Compositae) plant extracts for molluscicidal activity. Mem. Inst. Oswaldo Cruz 1999, 94, 411-412.

(24) Rodrigues, A. M. S.; De Paula, J. E.; Degallier, N.; Molez, J. F.; Espíndola, L. S. Larvicidal activity of some cerrado plants extracts agains. Aedes aegypti. J. Am. Mosq. Control Assoc. 2006, 22, 314-317.

(25) Accarini, R. B. Atividade fitotóxica de extratos foliares de Piptocarpha rotundifolia (candeia) (Less.) Baker - Asteraceae, Masters dissertation; Universidade Federal de São Carlos: Brazil, 2016.

(26) Rice, E. L. Allelopathy; Academic Press: Orlando, 1984.

(27) Dayan, F. E.; Duke, S. O. Natural compounds as next-generation herbicides. Plant Physiol. 2014, 166, 1090-1105.

(28) Köppen, W. Climatologia: con un estudio de los climas de la terra. Fondo Cult; Econ.: Mexico, 1948.

(29) Pivello, V. R.; Shida, C. N.; Meirelles, S. T. Alien grasses in Brazilian savannas: a threat to the biodiversity. Biodivers. Conserv. 1999, 8, 1281-1294.

(30) Zenni, R. D.; Ziller, S. R. An overview of invasive plants in Brazil. Rev. Bras. Bot. 2011, 34, 431-446.

(31) Anese, S.; Jatobá, L. J.; Grisi, P. U.; Gualtieri, S. C. J.; Santos, M. F. C.; Berlinck, R. G. S. Bioherbicidal activity of drimane sesquiterpenes from Drimys brasiliensis Miers roots. Ind. Crops Prod. 2015, 74, 28-35.

(32) Castellano, D.; Macías, F. A.; Castellano, M.; Cambronero, R. M. FITOMED. (automated system for measurement of variable lengths), Spanish Patent ES2155034 A1, 2001

(33) Hoagland, D. R.; Arnon, D. I. The water-culture method for growing plants without soil. Circ. - Calif. Agric. Exp. Stn. 1950, 347, 32.

(34) Kraus, J. E.; Arduin, M. Manual basico de metodos em morfologia vegetal; Universida, Ed.; Rio de Janeiro (Brazil): Seropedica, RJ, 1997.

(35) Grisi, P. U.; Forim, M. R.; Costa, E. S.; Anese, S.; Franco, M. F.; Eberlin, M. N.; Gualtieri, S. C. J. Phytotoxicity and identification of secondary metabolites of Sapindus saponaria L. leaf extract. J. Plant Growth Regul. 2015, 34, 339-349.

(36) Scavo, A.; Rial, C.; Molinillo, J. M. G.; Varela, R. M.; Mauromicale, G.; Macias, F. A. The extraction procedure improves the allelopathic activity of cardoon (Cynara cardunculus var. altilis) leaf allelochemicals. Ind. Crops Prod. 2019, 128, 479-487.

(37) Lorenzi, H. Manual of Identification and Control of Weeds. São Paulo: Institute Plantarum 2014.

(38) Cruz-Ortega, R.; Anaya, A. L.; Hernández-Bautista, B. E.; Laguna-Hernández, G. Effects of allelochemical stress produced by Sicyos deppei on seedling root ultrastructure of Phaseolus vulgaris and. Cucurbita ficifolia. J. Chem. Ecol. 1998, 24, 2039-2057.

(39) Iwabuchi, H.; Yoshikura, M.; Kamisako, W. Studies on the sesquiterpenoids of Panax ginseng C.A. MEYER. III. Chem. Pharm. Bull. 1989, 37, 509-510.

(40) Barrero, A. F.; Haídour, A.; Muñoz-Dorado, M.; Akssira, M.; Sedqui, A.; Mansour, I. Polyacetylenes, terpenoids and flavonoids from. Bupleurum spinosum. Phytochemistry 1998, 48, 1237-1240.
(41) Kunert, O.; Haslinger, E.; Schmid, M. G.; Reiner, J.; Bucar, F.; Mulatu, E.; Abebe, D.; Debella, A. Three saponins, a steroid, and a flavanol glycoside from. Achyrantes aspera. Monatshefte fuer Chemie/ Chemical Mon. 2000, 131, 195-204.

(42) Han, J.-T.; Bang, M.-H.; Chun, O.-K.; Kim, D.-O.; Lee, C.-Y.; Baek, N.-I. Flavonol glycosides from the aerial parts of Aceriphyllum rossii and their antioxidant activities. Arch. Pharm. Res. 2004, 27, 390395.

(43) Bohlmann, F.; Dhar, A. K.; Jakupovic, J.; King, R. M.; Robinson, $\mathrm{H}$. Two sesquiterpene lactones with an additional propiolactone ring from. Disynaphia halimifolia. Phytochemistry 1981, 20, 1077-1080.

(44) Bläs, B.; Zapp, J.; Becker, H. ent -Clerodane diterpenes and other constituents from the liverwort Adelanthus lindenbergianus (Lehm.) Mitt. Phytochemistry 2004, 65, 127-137.

(45) Liu, H.; He, H.; Gao, S.; Chen, C.; Shen, Y.; Hao, X. Two new diterpenoids from. Callicarpa pedunculata. Helv. Chim. Acta 2006, 89, $1017-1022$.

(46) Moreira, I. C.; Lago, J. H. G.; Young, M. C. M.; Roque, N. F. Antifungal aromadendrane sesquiterpenoids from the leaves of. Xylopia brasiliensis. J. Braz. Chem. Soc. 2003, 14, 828-831.

(47) Esposito, A.; Fiorentino, A.; D’Abrosca, B.; Izzo, A.; Cefarelli, G.; Golino, A.; Monaco, P. Potential allelopathic interference of Melilotus neapolitana metabolites on three coexisting species of Mediterranean herbaceous plant community. J. Plant Interact. 2008, 3, 199-210.

(48) Kordali, S.; Cakir, A.; Ozer, H.; Cakmakci, R.; Kesdek, M.; Mete, E. Antifungal, phytotoxic and insecticidal properties of essential oil isolated from Turkish Origanum acutidens and its three components, carvacrol, thymol and p-cymene. Bioresour. Technol. 2008, 99, 87888795.

(49) Verdeguer, M.; Blázquez, M. A.; Boira, H. Phytotoxic effects of Lantana camara, Eucalyptus camaldulensis and Eriocephalus africanus essential oils in weeds of Mediterranean summer crops. Biochem. Syst. Ecol. 2009, 37, 362-369.

(50) Rial, C.; Tomé, S.; Varela, R. M.; Molinillo, J. M. G.; Macías, F. A. Phytochemical study of safflower roots (Carthamus tinctorius) on the induction of parasitic plant germination and weed control. J. Chem. Ecol. 2020, 46, 871-880.

(51) da Silva, B. P.; Nepomuceno, M. P.; Varela, R. M.; Torres, A.; Molinillo, J. M. G.; Alves, P. L. C. A.; Macías, F. A. Phytotoxicity study on Bidens sulphurea Sch. Bip. as a preliminary approach for weed control. J. Agric. Food Chem. 2017, 65, 5161-5172.

(52) Teerarak, M.; Charoenying, P.; Laosinwattana, C. Physiological and cellular mechanisms of natural herbicide resource from Aglaia odorata Lour. on bioassay plants. Acta Physiol. Plant. 2012, 34, 15791582.

(53) O'Brien, T. P. The primary xylem. In Xylem cell development; Barnett, J. R., Ed.; Castle House Tunbridge Wells: Kent, 1981, pp 1446. 